\title{
Familian Mediterranean Fever: genetic characterization in Georgian population
}

\author{
Maka Ioseliani*, Maia Lekishvili, Nunu Shelia \\ From 21st European Pediatric Rheumatology (PReS) Congress \\ Belgrade, Serbia. 17-21 September 2014
}

\section{Introduction}

FMF is the most common mendelian autoinflamatory syndrome, resulting from autosomal recessive mutations in the MEFV locus. This disorder occurs most frequently among Sephardic Jewish, Arab, Armenian andTurkish populations. FMF occurs at lower frequeccies in other Mediterranean populations and ethnicities.

\section{Objectives}

In Georgia this disorder was detected mainly in ethnic Jewish and Armenians. We present cases of FMF in ethnic Georgians, that we have diagnosed in our department from the day of its foundation (2007) up today (2014).

\section{Methods}

We suspected FMF in 37 patients, the diagnosis was based on typical features. The FMF mutations were investigated in all patients. As a result FMF was proved in 37 cases is in investigation stage.

\section{Results}

Of the 37 patients $19(52.8 \%)$ are females, $18(47.2 \%)$ are males and the age ranged from 2 to16. A positive family history of FMF was noted in 5(13.5\%). Two patient has developed amyloidosis(mutationM694V/M694V). 27 of the patients had mutation M694V/M694V. 3 had mutation M680i/M694V. Another had M680I/M964V, M6801c/R761H, M680I/V726A, E148Q/M694V,M964V/ WT. We have not colchicines resistant patient.

\section{Conclusion}

Our study has approved that FMF occurs not only among Mediterranean population but among others including Georgians.In our population mostly frequent type of mutation is M694V/M694V.

M.lashvili Children's Central Hospital, Tbilisi, Georgia

\section{Disclosure of interest}

None declared.

Published: 17 September 2014

doi:10.1186/1546-0096-12-S1-P264

Cite this article as: loseliani et al.: Familian Mediterranean Fever: genetic characterization in Georgian population. Pediatric Rheumatology 2014

12(Suppl 1):P264.
Submit your next manuscript to BioMed Central and take full advantage of:

- Convenient online submission

- Thorough peer review

- No space constraints or color figure charges

- Immediate publication on acceptance

- Inclusion in PubMed, CAS, Scopus and Google Scholar

- Research which is freely available for redistribution
() Biomed Central
() Biomed Central (c) 2014 loseliani et al; licensee BioMed Central Ltd. This is an Open Access article distributed under the terms of the Creative Commons Attribution License (http://creativecommons.org/licenses/by/4.0), which permits unrestricted use, distribution, and reproduction in any medium, provided the original work is properly cited. The Creative Commons Public Domain Dedication waiver (http:/^creativecommons.org/publicdomain/zero/1.0/) applies to the data made available in this article, unless otherwise stated. 